報文 ORIGINAL PAPER No. 4

\title{
礬土一珪酸系耐火物のマトリツクスの研究
}

\author{
河内通・滑石直幸 \\ (播磨耐火煉瓦株式会社)
}

\section{Some Studies on Matrix in Alumino-silica Refractories}

By Tōru KOCHI and Naoyuki NAMEISHI

(Harima refractories Co.)

The performance of alumino-silica refractories for steel ingot making depends upon the nature of their matrix part which is changed by the minerals used as the raw materials as well as by the composition of the refractories.

In this study, various tests were carried out on several bricks having different matrix part which were prepared under definite moisture content of raw materials, fixed moulding pressure and burning temperature, using definite kinds of clay, pyrophyllite and grogs calcined at different temperatures.

It has found that the porosity of the brick was larger when the grog calcined at higher temperature was used.

Higher corrosion resistance was obtained for pyrophyllite matrix than precalcined clay matrix, whereas the spalling tendency was improved by the latter, in spite of its higher modulus of elasticity, due probably to its lower thermal expansion.

\section{緒㝘}

攀土一珪酸系酎火物の製造にあたっては，乙れが比 較的清浄な雾囲気の中で長時間高温飞曝される場 合 と，粉蝔，スラグ，溶鋼等の高温で，乙か子急激な機 械的侵蝕 (Erosisn), 㐫るいబ, 化学的侵蝕 (Corrosion）が同時飞行われるような環境核使用される場合 とでは，これらの条件を考慮した製造方式がとられな くてはならない, 後者の場合, 特飞製鋼工場飞特ける 造塊作業飞使用される諸種煉瓦については, スラグに よる侵蝕は，他の耐火物と同様とのマトリックス部分 飞集約的飞行われることほ，実験室的飞る，また実際 作業でも，しばしば認められる事実である。したがっ て充分飞揀瓦を焼締めて, 粒部分との融着を完全飞行 えば, この限りでるないが，これは他の重要な物理的

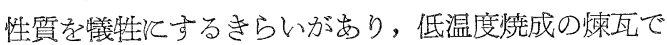
ほ，なるべくマトリックス部分飞耐蝕性をそな兄た原 料を配すべきである。特に造堍煉瓦は，鋼種，脱酸形 式，注入法，㐫るいは，スラグの成分等によって，消 耗度々著しく相違し,さらと使用時の煉瓦の熱間粘性 が大きく影響する。したがって徚瓦の成分としては，

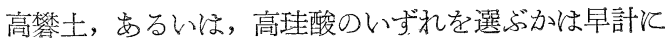
ほ断じ難いが，両者について共通する条件は真気孔率 の低いことである。このような見地からわれわれは 䙪土一珪酸系耐火物のマトリックスの研究の一部とし て, 粘土一蠟石一シャモット系の各点について, 各原 料起微粉碎した配合を作り，成形水分，成形圧，焼成
条件を一定にして，小型ブリケットを作製して燒成收 縮, 気孔率, 見掛比重の変化を比輘検傠した。京た配 合シャモットについては $900 \sim 1000^{\circ} \mathrm{C}, 1100 \sim 1200^{\circ} \mathrm{C}$, $1400 \sim 1500^{\circ} \mathrm{C}$ の範囲焼成されたるの 3 種を使用, シ ヤモット燒成度の影響も併せて考察した。な䅂，シャ モットと蠟石の配合割合を規則的变化させ，乙かも

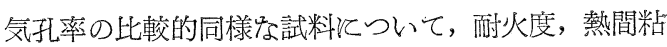
性, 荷重軟化, 熱膨脹, 耐侵蝕性, 弾性率, スポーり ング性等について比較検討した。

\section{I. 試料の作製}

本実験使用した原料隹，伊賀上野産木節粘土之， これを $900 \sim 1000^{\circ} \mathrm{C}, 1100 \sim 1200^{\circ} \mathrm{C}, 1400 \sim 1500^{\circ} \mathrm{C}$ と烺焼したシャモットと福渡蠟石（SK 29 番）を使用 した。福渡螠石はかなり多くの遊離石英を含有するパ イロフィライト系蠟石である. 粘土ふあらかでめ乾燥 し, シャモット招よび蠟石三者共に 1600 孔 $/ \mathrm{cm}^{2}$ 以下 飞微粉砕した。珄酸攀土系耐火物の諸性質を論ずる場 合, 原料独自の性質飞よって受ける影響渚しいが, 特飞水分粒度, 成形圧, 燒成温度等は成品䗲瓦の品質 そ極めて大きな要因となるものである。乙它がって， 添加水分々一応各配合飞ついて $10 \%$ とし，成形圧は $300 \mathrm{~kg} / \mathrm{cm}^{2}$ 飞一定した。各原料の配合は, 粘土一蠟 石一シャモットの三成分をとり, 三角図表上の各点 60 種を選び，それぞれ $1 \mathrm{~kg}$ の配合を作り，充分飞混 合して，とれを三等分し， $40 \times 115 \mathrm{~mm}$ の金型を使用 
乙て各種 3 ケずつ成形した。焼成は製造現場角窟を使 用し, $1400^{\circ} \mathrm{C}$ 前後飞焼成した。延焼成時間 130 時間を 要した。使用原料の化学成分呿よび耐火度をTable 1 飞示す.

Table 1 Chemical composition of raw materals

\section{Component}

$\begin{array}{lllll}\text { Row mate- } & \mathrm{SiO}_{2} & \mathrm{Al}_{2} \mathrm{O}_{3} & \mathrm{TiO}_{2} & \mathrm{Fe}_{2} \mathrm{O}_{3} \mathrm{CaO} \mathrm{MgO} \text { Ig.loss. SK }\end{array}$ $\begin{array}{llllllll}\text { Iga Soft Clay } 49.84 & 31.98 & 0.82 & 0.67 & 0.30 & 0.22 & 13.32 & 33.0\end{array}$ $\begin{array}{lllllllll}\text { Fukuwatari } & 7.30 & 18.05 & 0.06 & 0.59 & 0.13 & 0.20 & 3.27 & 28.5\end{array}$

Fig. 1 亿配合表を示す.

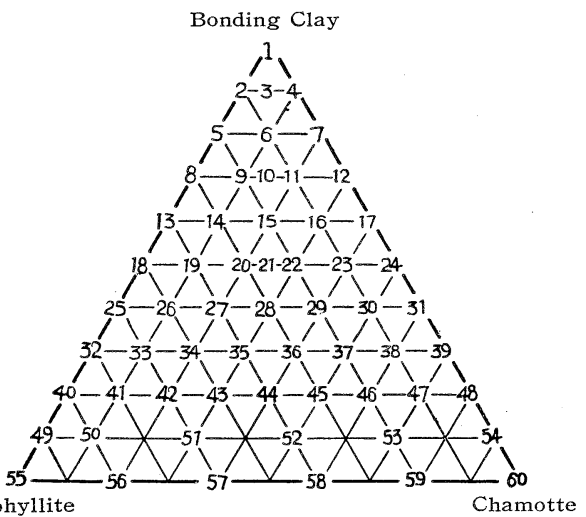

Fig. 1 Raw material component of each briquette under test Bonding Clay

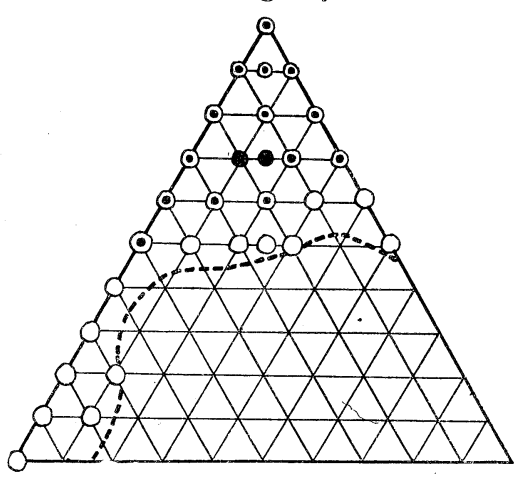

Pyrophyllite

Chamotte

Crack State

- Large 0 midle $\bigcirc$ Small

Fig. 2 Cracking appearance after firing
II. 試験方法と実験結果

上記各温度焙成シャモットを使用した粘土一蠟石一 シャモット各配合焼成物全数について, 燒成後の重 裂，成形時のラミネーション，爟成膨脹収縮率，見掛 比重，見掛気孔率を測定し，な拈粘土 $30 \%$ を配合し そシャモット蠟石系とついて，耐火度，熱間粘性，荷 重軟化, 加熱膨脹性, 弾性率, スポール性等を測定し 粘土 $20 \%$ 配合したシャモット蠟石系の各配合につ き，塩基性鉣㳯による耐侵蝕性を比較検討した。

試験方法は次ぎの通りである。

A）熱間粘性試験堅型タンマン管電気炉中に, $20 \oint \times 110 \mathrm{~mm}$ の試料をニクロム線で懸垂し，下部よ り $1 / 3$ の所を加蓺, 溶融, 切落させ, 切落初めの温 度, 切落終了の温度招よび切落後の試料の㱏びと, そ

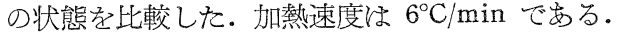

B）加熱膨脹試驗鋻型押棒式装置を使用. 試料 の大きな $16 \oint \times 60 \mathrm{~mm}$ の丸棒を用い，加熱速度は 4 ${ }^{\circ} \mathrm{C} / \mathrm{min}$, 最高温度 $1000^{\circ} \mathrm{C}$ までを測定する。

C) 弾性率常温弾性率測定には, 河嶋式試験装 置を使用. 試料の大きさ $3 \times 20 \times 110 \mathrm{~mm}$ の平板を供 試した。尔和測定值の算出には，鏡々尺度との距離 $1000 \mathrm{~mm}$ 亿和ける挺子倍率 1163 倍, 荷重倍率 5.86 倍の恒数を用いた。

D） スポーリング試料の大きさ $40 \mathrm{~mm}$ 立方. 全面加熱，急熱 $1000^{\circ} \mathrm{C}$ ，水冷方法を用い，重裂開始括 よび破壊までにいたる回数で比較した。

E）侵蝕抵抗性試験堅型エレマ電気炉を使用し 試料の大きさ $25 \Phi \times 110 \mathrm{~mm}$ を供試した。黑鉛坩堝の 内容 $60 \oint \times 170 \mathrm{~mm}$, 試験温度 $1400^{\circ} \mathrm{C} \times 20$ 分である。 使用スラグの成分は $\mathrm{SiO}_{2} 20 \%, \mathrm{FeO}+\mathrm{Fe}_{2} \mathrm{O}_{3} 35 \%$ ， $\mathrm{MnO} 5 \%, \mathrm{CaO} 25 \%$ のかなり $\mathrm{Fe}$ 分の高い平炉ス ラグを使用した。スラグほ每回これを取換え，1回に 3 個の試料を同時に挿入乙て比較した．被蝕率はスう グ面下の被蝕された容積に対する原容積の比率で示し た。

Fig. 2 V配合の変化に伴う焼成後の重裂状態を示 し,Fig. 3 にシャモット㜔成度を異にした系について 収縮率の分布図を，Fig。 4 亿見掛比重，Fig.5 亿気

Table 2 Characteristics of matrix bricks, composed from pyrophyllitic to chamotte rich

\begin{tabular}{|c|c|c|c|c|c|c|c|}
\hline \multirow{2}{*}{ No. } & \multirow{2}{*}{ SK } & \multicolumn{3}{|c|}{$\begin{array}{l}\text { Relative viscosity at } \\
\text { high temperature }\end{array}$} & \multicolumn{3}{|c|}{$\begin{array}{l}\text { Refractoriness } \\
\text { under load }\end{array}$} \\
\hline & & $\begin{array}{l}\text { Start } \\
\text { softening }\end{array}$ & $\begin{array}{l}\text { Softening } \\
\text { down }\end{array}$ & $\begin{array}{l}\text { Elonga- } \\
\text { tion }\end{array}$ & $T_{1}$ & $T_{2}$ & $T_{3}$ \\
\hline 32 & 29.5 & & ${ }_{1685}^{\circ} \mathrm{C}$ & $\mathrm{mm}_{41}$ & ${ }_{1480}^{\circ} \mathrm{C}$ & ${ }^{\circ} \mathrm{C}$ & $\begin{array}{r}{ }^{\circ} \mathrm{C} \\
1550\end{array}$ \\
\hline 33 & 30.0 & 1620 & 1690 & 50 & 1490 & 1535 & 1590 \\
\hline 34 & 30.4 & 1630 & 1695 & 33 & 1495 & 1520 & 1580 \\
\hline 35 & 30.6 & 1635 & 1697 & 100 & & & \\
\hline 36 & 31.0 & 1640 & 1700 & 51 & & & \\
\hline 37 & 31.3 & 1640 & 1700 & 29 & & & \\
\hline 38 & 31.5 & 1640 & 1700 & 26 & & & \\
\hline 39 & 32.0 & 1650 & 1710 & 25 & & & \\
\hline
\end{tabular}

\begin{tabular}{|c|c|c|c|c|c|}
\hline \multirow{2}{*}{$\begin{array}{c}\text { Expansion } \\
\text { Percent at } \\
1000^{\circ} \mathrm{C}\end{array}$} & \multicolumn{2}{|c|}{$\begin{array}{l}\text { Spalling } \\
\text { resistant }\end{array}$} & \multirow{2}{*}{$\begin{array}{l}\text { Modulus of } \\
\text { elasticity } \\
\mathrm{kg} / \mathrm{cm}^{2} \times 10^{5}\end{array}$} & \multicolumn{2}{|c|}{$\begin{array}{l}\text { Chemical } \\
\text { comp. }\end{array}$} \\
\hline & $\begin{array}{l}\text { Crack } \\
\text { start }\end{array}$ & $\begin{array}{c}\text { Break- } \\
\text { down }\end{array}$ & & $\mathrm{SiO}_{2}$ & $\mathrm{Al}_{2} \mathrm{O}_{3}$ \\
\hline 0.910 & 1 & 6 & 0.515 & 70.82 & 27.00 \\
\hline 0.831 & 1 & 4 & 0.551 & 69.54 & 28.34 \\
\hline 0.776 & 1 & 6 & 0.775 & 68.10 & 29.63 \\
\hline 0.739 & 1 & 6 & 0.845 & 66.38 & 29.94 \\
\hline 0.676 & 1 & 6 & 0.827 & 65.68 & 31.13 \\
\hline 0.650 & 1 & 7 & 1.169 & 64.78 & 31.96 \\
\hline 0.617 & 1 & 8 & 1.261 & 63.86 & 32.12 \\
\hline 0.593 & 2 & 8 & 1.462 & 62.34 & 33.17 \\
\hline
\end{tabular}


孔率の変化の傾向を示与. Table 2 飞粘土 $30 \%$ 添加 せる場合のシャモット䗵石系の耐火度，化学分析，熱 间粘性, 荷重軟化 $1000^{\circ} \mathrm{C}$ 飞和ける膨脹率, スポール 性, 弾性率等を示す.

Fig. 6 V加熱膨脹曲線（粘土 30\%), Fig. 7 飞弾 性率，Fig. 8 亿塭基性鉱㳯による侵蝕率を示す（な特 酎赨性の比較試料怗粘土 $20 \%$ 添加の配合について行 った).Fig. 9 飞気北率と収縮率との相関を示す。

\section{III. 結果の考 察}

1）焼成龟㤠上ラミネーション シャモット煉瓦

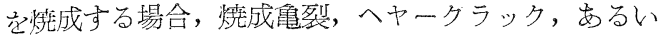
は成形時に生ずるラミネーション等ふ, 現場的に問題 になる点であり，特に生粘土を多量飞使用するような 場合には，荻成方法を充分飞検討しなければならな
い. 攀土一珪酸系煉瓦を製造する場合，使用目的にし たがって，配合比の変更は常に行われるととであり， これて怑ってマトリックス部分の粘土, シャモット, 蠟石比は異なって来る。今回同一条件で焼成した各配 合の燒成後の状態ね Fig. 2 飞見られるようである。 す䒺方々，

（A）マトリックス部分の生粘土が $50 \%$ より多く なれば，大体て䋇いて大なり小没りの重裂が入 ってくる.

(B) 蠟石一粘土系ではほとえど重裂が入り，特に 蠟石成分が多くなるとラミネーションが出る傾 向が強い。

（C）したがって，シャモット煉瓦を製造する場合 そは,シャモットの特飞微粒子の量と, 結合粘 土の割合を考える必要があり，蠟石をマトリッ

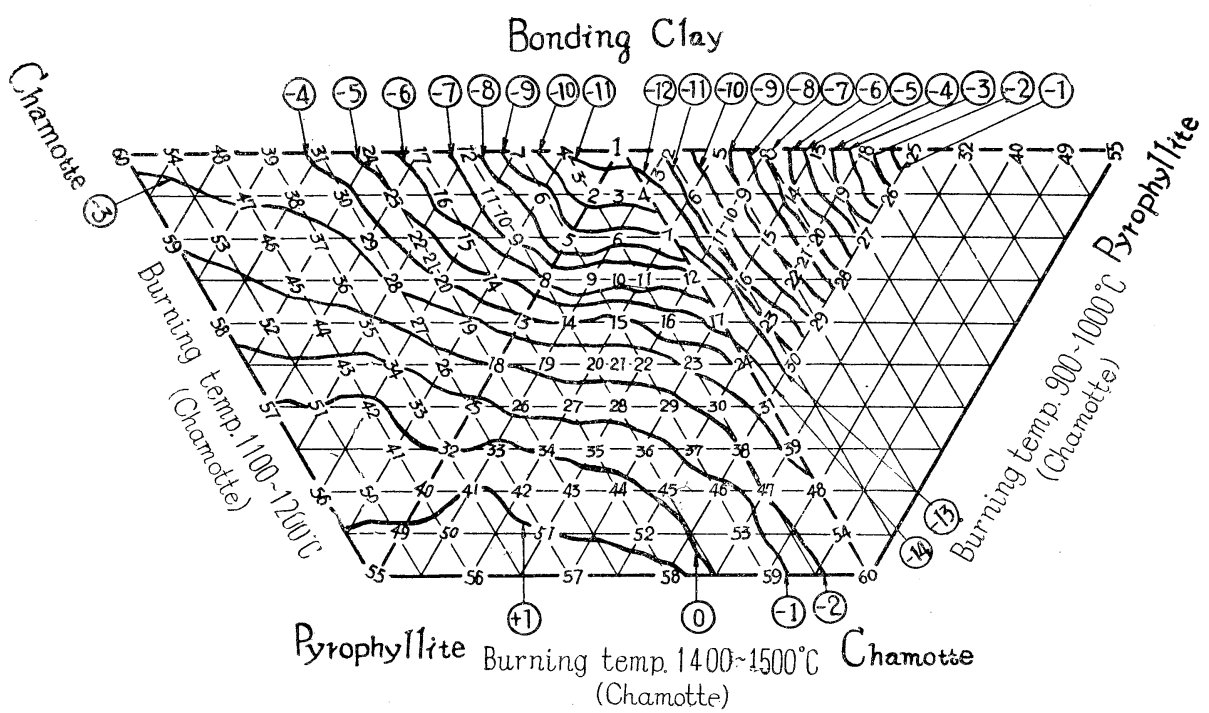

Fig. 3 Linear changes after firing in periodic kiln

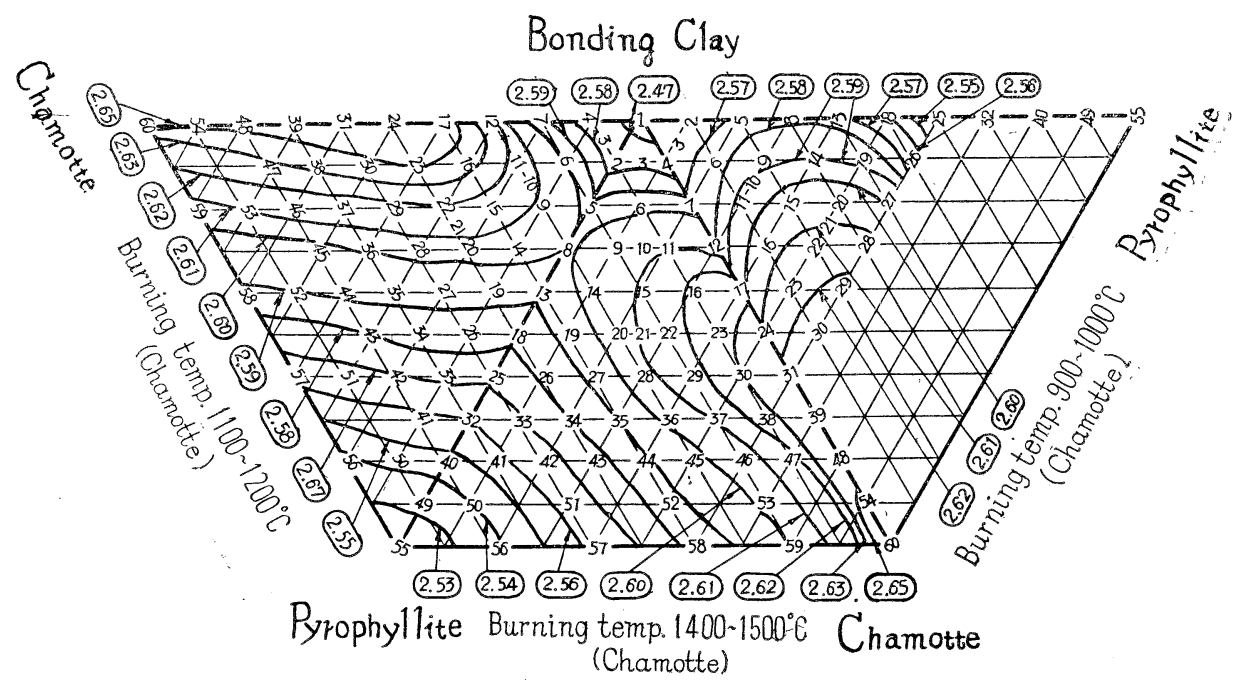

Fig. 4 Distribution of apparent specific gravity after firing. 
クス部分に多く配合する場合には，マトリック ス部に 20\% 以上のシャモットを配した方が良 W.

2）収縮率収縮率は寸法を規定する上に最も重 要な要素である。今, 粘土一蠟石一シャモットの各系 について同一燅成条件で, シャテットの焼成度が如何 飞収縮率に影響するかを検するに，

(A) $900 \sim 1000^{\circ} \mathrm{C}$ 前後で烺绫したシャモットを使 用する場合，収縮率ほ症とえぞ蠟石の添加量の み注って左右される。

(B) この場合，低温煆焼シャモット単味のマトリ ックスね，生粘土単味よりも収縮率が大きい。 すなわち，粘土とシャモットを添加する程収縮 率は増加している。

(C) 粘土一蠟石系では，蠟石約 70\%で膨脹収縮 が0になっている.さらと蠟石を増加すれば， 永久膨脹を示すが，気孔率の項で見られるよう V 70\% 蠟石添加附近の場合が最も気孔率が高 く, 蠟石単味になると, 却ってまた低下する傾 向がある。

(D) 全般的にシャモットの筧成度が高くなれば， 収綰率が減少与るが，シンタ一の移動は蠟石沶 よびシャモット配合量の多い分野で著しい。

(E) シャモットの䇢成温度が高くなると伴って， 収縮率な粘土の影響が著しくなり，蠟石とシャ モットの配合比にばあまり関係がなくなる。

（F）乙たがって，寸法を規定する面からは，マト リックス部のシャモットは出来るだけ高温焼成 し，粘土は $50 \%$ 以下が望ましい。

3）見掛比重の変化見掛比重は, 原料の転移性 上密封気孔の生成量の多寡によって異なってくる。一
般飞蠟石は $1300^{\circ} \mathrm{C}$ 前後から，また粘土は $1100^{\circ} \mathrm{C}$ 前 後から低下するが, 高アルミナ質原料は, 却って増加 する傾向がある。今回実験に供した蠟石は，かなり遊 離石英圭有するものであり，木節粘土は $1100^{\circ} \mathrm{C}$ 以上 $1500^{\circ} \mathrm{C}$ までは，ほとんで焼成による変化は見られない ものでめった。各配合について検討すれば，次のよう である。

(A) 見掛比重の低下は主として䗵石の増加割合に 影響され，末た粘土配合の多い分野で，見掛比 重が低下するのは，密封気孔が増加するためと と考学らる。

(B) 粘土一シャモット系で，シャモットが増加す るに伴って，獟成後見掛比重が増加するのは， 微粉砕と焼成によってシャモット中の密封気扎 が開放気孔に変るためと思われる。

4) 見掛氢孔率の変化攀土一珪酸系耐火物の気 孔率は, 主に耐蝕性, あるいはスポール性の見地加ら 大きな問題となって来る。

諸石 ${ }^{1}$ はシャモット霓でほ $5 \%$ 以上の密封気孔の 存在が，極めて耐スポール性を減ずることを，耐圧强 度の低下率から実験的に証明しているが，耐スポール 性は適当索粒度調整，あるいは Ensner ${ }^{2)}$ 等の述べて いるょうに, 気北の状態，さらには，藤井 ${ }^{3}$ の述ベて

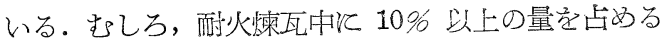
マトリックスのガラス質の成分行影響されるところが 大きいと思われる。したがって, 煟瓦の気孔率を論ず る場合，シャモット粒子自体の気扎率よりも，それら の結合体の気北率，あるいは，気北の形態が問題とな って来る。委た，シャモットの燒成度，あるいは，蠟 石微粉の混合割合から受ける影響も，実際徚瓦を製造 する場合には併せて考光る必要がある。シャモット一

\section{Bonding Clay}

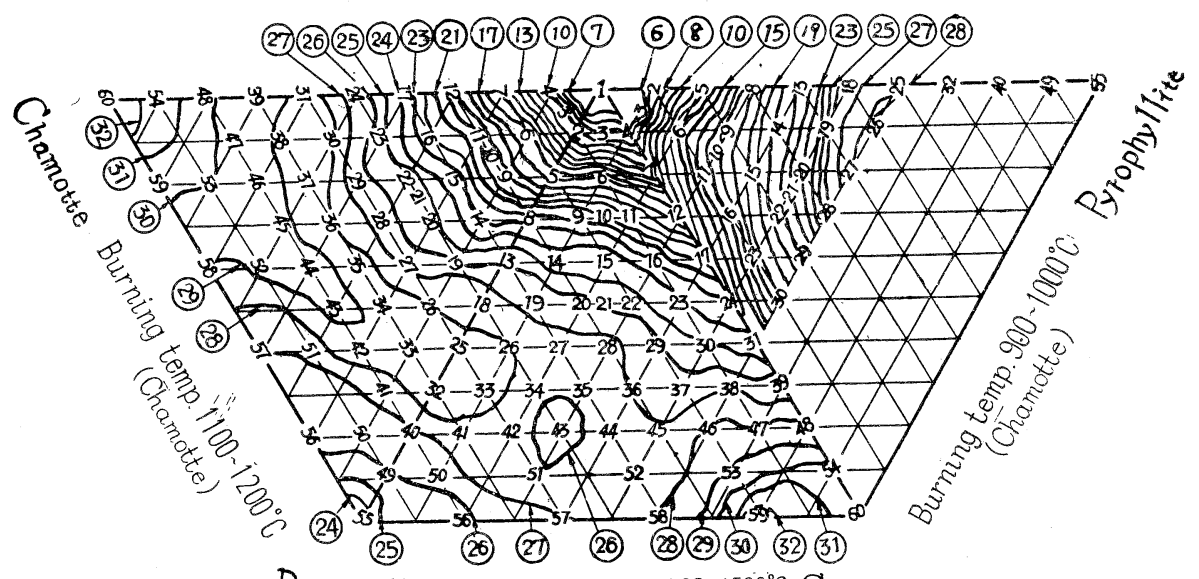

Pyrophyllite Burning temp. 1400 1500 C Chamotte

(Chamotte)

Fig. 5 Apparent porosity distribution after firing 
蠟石一粘土系の各点について得られた結論ね, 次のよ うである。

（A）煉瓦の燒成条件を一定にした場合, 烺焼シャ モットは $1000^{\circ} \mathrm{C}$ 前後で燒成されたるのの方が 高温燒成のシャモット飞比して著しく気孔率は 小さくなる。

(B) 粘土一シャモット系では, シャモットの焼成 度の如何にかかわらず，添加シャモット $30 \%$ 以上で，密封気孔を減ずるととが出来る。

(C) 粘土一シャモット系蠟石を添加与る場合, 低温燒成シャモットを使用した場合洼，蠟石の 増加と共気孔率は増加するが, 高温燒成シャ モットを使用しそ場合ほ, シャモット一蠟石の 量比よりも，粘土の影響の方が大きい。

(D) $1200^{\circ} \mathrm{C}$ 以上でシャモット觉焼成すれば，シャ モット焼成度の気扎率への影響は㴽とんぞ現わ れない。これは木節粘土が $1200^{\circ} \mathrm{C}$ 以上で見掛 比重, 気扎率, 収縮率が一定するためと考兄ら れる。

(E) 粘土一蠟石系では, 蠟石 60 70\% 附近が最 も気孔率高く, この意味で, 蠟石質マトリック ス配合とするためには適当な結合剤を添加する ととが望ましい。

5）収縮率と橆孔率の関係ブローテイング性， その他特殊な場合を除いて, シャモット煉瓦では一般 收収縮率と気孔率とは逆比例の関係にあるのが普通で ある。シャモット一蠟石一粘土系では, 蠟石の配合量 怔增加する程, 気孔率は増加し, 収縮率は減少する が，二，三の留意すべき点を述べれば次の通り。

(A) $1000^{\circ} \mathrm{C}$ 前後に煆焼したシャモットを使用すれ ば, 收縮率と気孔率とは, むしろ逆の関係が出 る。すなわち、シャモットの添加量を増加する 飞つれて収縮率が増加し, さら反気孔率子増加 する。

(B) 高温焼成シャモットと粘土間では, 直線的逆 比例関係汇ある。

(C) 蠟石の多い分野では，収縮率が減少するにも かかわらず, 気孔率る減少する。

\section{6) 膨涱性状}

（A）純シャモット質から蠟石質炕変るとしたがつ て膨脹率が大きくなるととは常識通りである.

(B) クリストバライトとトリジマイトの変態膨脹

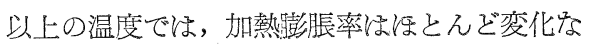
く，珪石煉瓦のマトリックス，すなわち（トリ ジマイト+ガラス質）の集合体より著しく膨脹 率は小さい。

（C）蠟石質からシャモット質に移るにしたがい， クリストバライトの変態澎脹率が低下し, 転移

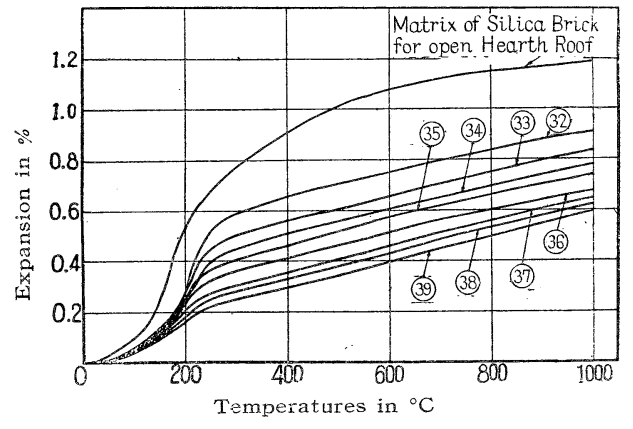

Fig. 6 Thermal expansion of briquette from Chamotte to pyrophyllitic matrix

温度は $200^{\circ} \mathrm{C}$ と $230^{\circ} \mathrm{C}$ 前後の 2 種がある.

(D) トリジマイトの変態澎脤もみられるが，その 消長要不規則である。

7）弾性率とスポール性蠜土一珪酸系耐火物化 限らず, 耐火煉瓦の具備ず゙き最子重要な特性は, 耐 蝕性と耐スポール性である。耐熱性夌支配する要因 ほ, 機械的強度, 熱 (温度) 伝導率, 弾性率, 膨脹係 数等の主要因の添か, 原料の産地沉よる特性 ${ }^{4}$, ドラ イプレス, または Stiffmud 等の成形要团 ${ }^{5}$, 気北率 打よび密封気孔の量 ${ }^{1)}$ と形態( ${ }^{6}$, 粒度組成, 化学成分, 構 成鉱物，シャモットと結合粘土の成分的な組合わせ， ガラス質物の性質等,複杂椎度要因によって影響される。

元来シャモット煉瓦を製造する場合㴛変化時に 生ずる局部的歪を最少ふらしもるため, ひいてね，均 一な被蝕性を与兄るために统, シャモットと結合粘土 は同一原料を配すべきであるが, 原料淛約されて数 種の原料を配合するのが一般である。結合粘土を異に するシャモット煉瓦の耐熱性について, 山内 ${ }^{7)}$ は化学 的には比較的珠酸質のシャモット飞ついては,アルミ

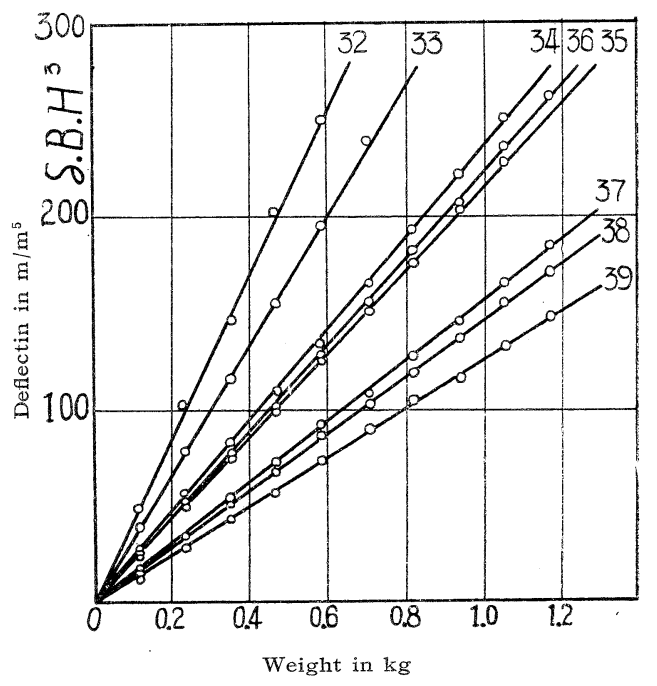

Fig. 7 Relation between deflection and weight in chamotte pyrophyllite matrix 
ナ飞富む粘土がよく，反対にアルミナ質のシャモット に対しては，比較的理酸飞富も粘土を配した方がよ く，物理的には中位の弾性率を示するの（これと関し てね W.R. Morgan ${ }^{8)}$ も同一結論孛出している) がよ いとされ，河合幸三 ${ }^{9}$ は化学成分的 40\%で，構成鉱物としてはカオリナイトがよいと結え でいる。スポール性に及添す弾性率と澎脹係数との間 そは, M.C. Booze ${ }^{9}$ は比較的高い膨脹係数を示する のも, 高い弾性を示すととによって, スポール性が付 与されるととを論じている。すた，多孔質な徚瓦い， 低温度では比較的強いが，激しい熱変化注して非常 飞不安定宗傾向が見党るもので, 煉瓦の気孔率より耐 熱性を判定する場合には往々䛊りが生ずることにな る。乙たがって，上記の諸説から，一応スポール性を 左右すると思われる要因, す交わち, 成形水分, 圧

\section{$\mathrm{SiO}_{2}-\mathrm{Al}_{2} \mathrm{O}_{3}$} Matrix brick

Clay Pyrophy. Chamotte

$30 \quad 70$

$30 \quad 60 \quad 10$

$30 \quad 50 \quad 20$

$30 \quad 40 \quad 30$

$30 \quad 30 \quad 40$

$30 \quad 20 \quad 50$

$30 \quad 10 \quad 60$

$30 \quad 0$

\begin{tabular}{|c|c|c|}
\hline $\begin{array}{l}\text { Modulus } \\
\text { of } \\
\text { elasticity }\end{array}$ & $\begin{array}{l}\text { Matrix brick } \\
\text { from } \\
\text { siliceous stone }\end{array}$ & $\begin{array}{l}\text { Modulus } \\
\text { of } \\
\text { elasticity }\end{array}$ \\
\hline $0.515 \times 10^{5}$ & Tamba-Akasiro & $1.375 \times 10^{5}$ \\
\hline $0.551 \times 10^{5}$ & Tamba-Aosiro & $1.773 \times 10^{5}$ \\
\hline $0.775 \times 10^{5}$ & Wakasa-Aosiro & $2.126 \times 10^{5}$ \\
\hline $0.845 \times 10^{5}$ & Youra-Chart & $0.689 \times 10^{5}$ \\
\hline $0.827 \times 10^{5}$ & $\begin{array}{l}\text { Mikawa } \\
\text { Quartzite }\end{array}$ & $1.760 \times 10^{5}$ \\
\hline $1.161 \times 10^{5}$ & Silica brick bat & $0.929 \times 10^{5}$ \\
\hline $1.261 \times 10^{5}$ & $\begin{array}{l}\text { Silica brick of } \\
\text { openhearth roof }\end{array}$ & $0.721 \times 10^{5}$ \\
\hline $1.402 \times 10^{5}$ & & \\
\hline
\end{tabular}

力, 粒度, 焼成法, 気孔率等を除いた蠟石一粘土一シ ャモット系についていわゆるマトリックス部分につい て弾性率を測定し, 澎脹性状とも併世て, 耐スポール 性を比輷検討乙てみた。 な招, Table 3 の弹性率は $0.6 \mathrm{~kg}$ 荷重の場合の值を示した。

（A）マトリックス部分の弾性率は，シャモット采 より蠟石質飞移るとつれて渐次低下寸る。

（B）耐スポール性は，シャモット質の方が蠟石質 よりやや強い。これはシャモット質の低膨脹性 飞起因すると思われる。

（C）したがって，蟃石質マトリックス部は耐スポ

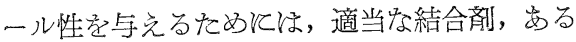
いは鉱化倣を使用して，ガラス質の組成を変党 る必要が女る。

（D）な扮，珪石煉瓦のマトリックス部の弾狌率皂， Table 3 のよらと先の成因, 転移性によって, かなりの差違が認められ，との点は蠟石，ある いは，粘土について子究明する必要がある。

珪石煉瓦ふ，マトリックス部単味よりも粘度調整を 行うと, 弾性率は $1 / 2$ 程度飞減ずる。これ粒度調整

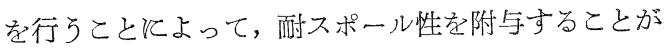
出来るという実験的基礎を与えている。
8）耐火度, 熱間粘性, 荷重軟化の諸問題攀土 一珪酸系酎火物の耐火度についてほ, 藤井の述べてい るよう飞, 粒度, あるいは, 焼成温度差によってる同 一原料で SK 2 番前後の差違が認められて招り，一般 には原料中の不純物の影響を受けて, 原料の $\mathrm{Al}_{2} \mathrm{O}_{3}$ 之 $\mathrm{SiO}_{2}$ の比が，そのまま標準鋳の成分比飞よる温度と 一致しない.

今回行ったシャモット, 蠟石, 粘土系について, シ 中モット質より順次蠟石を増加した配合飞ついて，す なわち, 成分的飞は $\mathrm{Al}_{2} \mathrm{O}_{3}$ が順次低下する方向飞つい て, 耐火度, 軟化切落試験特よび荷重軟化試験起行っ たととろ，大体次のような結果を得た。

(A) 酎火度は蠟石質飞なるにしたがってるちろん 低下するが，蠟石が増加するにしたがって標準 曲線より低下率が大きくなる。

(B) 軟化切落試験飞よ って得られた切落開 始温度と切落温度 は，ほとんど標準曲 線と同一傾向をたど り，耐火度は切落開 始温度と切落温度の 中間位置する。

（C）切落状態将，シャ モット質より蠟石質 そ変るにしたがって

漸次粘りを增す。

(D) 荷重軟化温度は， $\mathrm{Al}_{2} \mathrm{O}_{3}$.の増加化伴い上昇す る. シャモット蠟石質煉瓦の熱間粘性の問題 ほ，特耐侵蝕性を論ずる場合飞重要な要因と なるるので，これらと作用する添加荗招よびス ラグの影響等の問題も同時飞取上げねばならな W.

9）耐蝕性礬土一珪酸質耐火物の侵蝕はいわゆ る機械的侵蝕 (Erossion) 々化学的侵蝕 (Corrosion) そ大別される. 製鋼工場で，最る多く耐蝕性を要求さ れる煉瓦汇造塊用煉瓦があり，乙の良否が直接飞鋼塊， の原単位と歩留飞影響してくる。したがって，過去多 くの実験研究が, 造塊煉瓦特飞取鍋内張, スリーブ, ノズル，湯道煉瓦等を中心行われている。例光ば， 煉瓦の化学成分から， $\mathrm{Al}_{2} \mathrm{O}_{3}$ 分が高い庘が侵蝕治強い とい万説飞里井孝三郎 ${ }^{10)}$, W.F. Ford ${ }^{11)}$, 河合幸三 12)，D.N. Poluboyarinov ${ }^{13}$ 等の研究があり, 高珪 酸質が強いという説飞, A.T. Green ${ }^{14)}$, Karl-Otto $Z \mathrm{Zimmer}^{15)}$ ，守川喜久男 ${ }^{16)}$ 等の報告がある。な称，丹 羽庄平 ${ }^{17}$ ，小沢卯三郎 ${ }^{18)}$ 等は成分的飞は $\mathrm{Al}_{2} \mathrm{O}_{3} 30 \%$ 前 後が良かったと報告している。R.B. Snow ${ }^{19}$ はノズル の侵蝕機構, ブローティング性と非ブローティング性 


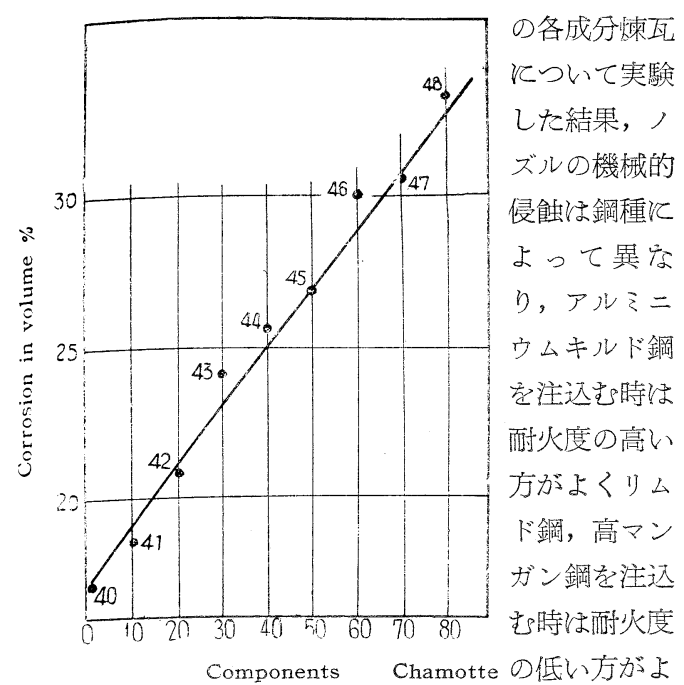

Fig. 8 Corrosion resistance of いとし, これ chanotte-pyrophylite matrix $\mathrm{W}_{\mathrm{SiO}}-\mathrm{Al}_{2} \mathrm{O}_{3}$ from basic open hearth slag.

系のカイヤナ

イト質煉瓦江 MnO または $\mathrm{FeO}$ が添加された場合, 最初の溶液は $1200^{\circ} \mathrm{C}$ 前後で起るととを示し, この液 体は珪酸分の高い粘土との反応によって出来た粘性の 高い溶液に比較すれば流動性の大きいととによるとし ている。一方 Mc.Callom ${ }^{20)}$ \& $\mathrm{Al}_{2} \mathrm{O}_{3}-\mathrm{SiO}_{2}-\mathrm{CaO}$ 系で $\mathrm{CaO}$ 25 50\% の量汶対しては $\mathrm{Al}_{2} \mathrm{O}_{3}$ の多いほど，粘 度の大きくなることを示し，また， $\mathrm{Al}_{2} \mathrm{O}_{3}-\mathrm{SiO}_{2}$ 系の鉣 㵏中への搪散のような場合は, 粘性係数注搪散係数汇 反比例するととを示している。諸石勝 ${ }^{11}$ はノズル搪大 量の要因として, 注入温度, 注入法, 脱酸形式, 鋼の 成分 (C, Mn, Fe) 和よび煉瓦の品質飞ついて, 現場的 作業に統計的手法を適用して検討した結果，注入量の 変動，注入方式，注入温度が有意であったとしてい る. その他荷重軟化温度の高い程, あるいは, $T_{3}-T_{1}$ (軟化温度差) の高い程, 侵蝕率が低いとい5説や15), 気孔率, 耐圧強度, 鉱物組成 ${ }^{12)}$, 熱間ガラ 粘性等数多くの報告がなされているが, 要すると侵蝕 （機械的招よび化学的）は徚瓦の組織面汶対して均一

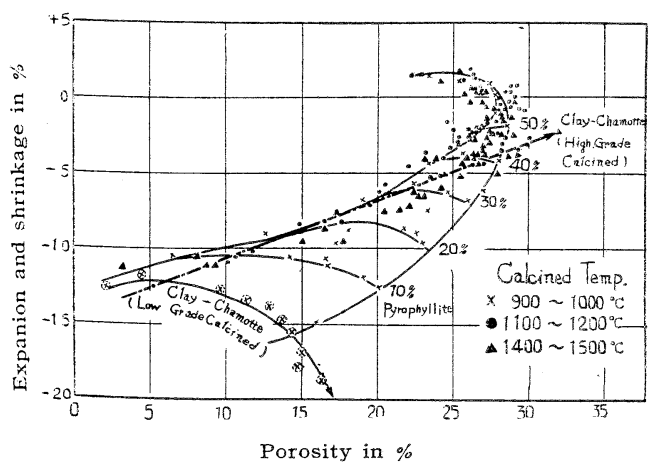

Fig. 9 Relation between the linear change and App. porosity after firing
に行われるといらととが, 最も重要な条件と考光られ る。との条件を満すょう 整, 成形法を適用し, さらに侵入するスラグの成分を 考慮して，充分尔熱間粘性を与光るようにすべきであ る. 焼結耐火物江括いて，特们耐蝕性を考光る場合飞。 は，粒子とマトリックス部分は同一原料を配するとと が理想であり（アメリカ Swank 製ブローティング性 ノズル，スリーブ等の組織)，さもなくば表面係数を考 兄てマトリックス部にやや耐蛤性の強い, 原料を配し, さらに,マトリックス部分の粘性を考慮すべきである。

攀土一理酸質取鍋煉瓦汇は従来から高アルミナか, 高珪酸かの論議がしきりに行われているが，これねス ラグの成分と量, 䀘瓦の気孔率和よび作業方式等の影 響が大きく，決定的にはをだ最良の組成は求められて いないが，組織的には気孔率が低く，物理的には僅か 飞二次膨脹を示すととが必要である. 今回試作した粘 土一蠟石一シャモット系のかなり一定した条件下での 塩基性スラグによる侵蝕試験の結果注次のようであ る.

（A）結合粘土 $20 \%$ 使用し，蠟石を 0 80\% 配 合したシャモット一蠟石質マトリックス徚瓦に ついて，浸漬法で $1400^{\circ} \mathrm{C} \times 20 \mathrm{~min}$ (試料の大き さ25£ $\times 110 \mathrm{~mm})$ 試験した結果, 蠟石質注シャ モット質の約 $1 / 2$ の被蝕率しか示さなかった。

(B) 煉瓦の化学成分から云って $\mathrm{Al}_{2} \mathrm{O}_{3} 30 \%$ が特忆 良いというととも言光ず，また，耐火度と荷重 軟化温度から云壳壮, むしろ低い方がよい。

（C）侵蝕率はマトリックス部の粘性と関係があり 熱間粘性の強い蠟石質がシャモット質より耐蝕 性がある。

(D) 今後はさら飞各種粗成のマトリックス部に $\mathrm{MnO}, \mathrm{FeO}, \mathrm{CaO}$ 等を加克たものの熱間粘性を 比較検討し，あるいは，煉瓦汇添加してマトリ ックス部の粘性を改良する鉱化刘, あるい結 合剛を究明ずべきである。

\section{結論}

以上, 樊土一珪酸系耐火物のマトリックスの研究の 一部之乙て，極く限られた原料とついて，冷間と熱間 物理化学性を検討したが, 内地産原料以鉱床の規模る 小さく(したがって成分の変化が大きく) かつ高攀土 質原料の不足している現在，なるべく適材を適所に， あるいは原料の配合にそれぞれの長所を織达をことが 必要之考觉る. 気孔率, 化学成分等のほぼ似た煉瓦で 使用結果飞著しい差違の生ずることは常に経験すると ころであり, この意味でマトリックス部の研究は, こ れらの総合的な基礎を与兄るものであり, 従来の煉瓦 全体の化学成分, あるいは酎火度乞の他の品質の測定 
基礎比して，煉瓦の品質を判定する譴りから，早急 に脱却した汗ればならないと思考する次第である。

\section{参考 文 献}

1）諸石勝, 播磨酎火煉瓦株式会社創立二周年記念 講演会

2) G. R. Ensner and W. S. Debenham, Am. Ceram. Soc. Bull., 489 (1952)

3) 藤井稔, 宰協, 57 [634] (1949)

4) G. R. Ensner and W. S. Debenham, Am. Ceram. Soc. Bull., 489 (1952)

5) 同上

6) C.E. Moore, Trans. Brit. Ceram. Soc., 48 [5] 176-85 (1949)

7) 山内俊吉 - 加藤左織, 嚜協, 51 [604] (1943)

8) W.R. Morgan, J. Am. Ceram. Soc., 14, 913 (1931)

9) M.C. Booze and S.M. Phelps, J.A.C.S., 8, 361 (1925)

10）里井莩三郎，密協，48，12-18（1940）
11) W.F. Ford, J. White, Trans. Brit. Ceram. Soc., 5 [11] 461-503 (1951)

12）河合幸三・篠原武夫，穼協，51［601］(1943)

13) D.N. Poluboyarinov and I.V. Smirnova, Ogneupory, 17 [2] 71-81 (1952)

14) A.T. Green, A.E. Dodo, Iron and Steel, Spec. Rept. No. 32, 293-322 (1946)

15) Karl-otto Zimmer, Stahl und Eisen, 73, 411 -416 (1953)

16）守川喜久男・小谷良男, 耐火物工業，17，20816 (1953)

17) 丹羽庄平，耐火物工業，16(1953)

18）小沢卯三郎外, 名古屋工業技術試 験 所 報告, 3 [9] (1954)

19) R.B. Snow and James A Shea, J.A.C.S., 32 [6] 187-94 (1949)

20) Mc. Callom and L.R. Bavrett, Trasss. Brit. Ceram. Soc., 51, 523 (1952)

( $7 / 15 / 55$ 受付)

\begin{tabular}{|c|}
\hline 報 \\
ORIGINAL PAPER \\
NO. 5
\end{tabular}

\section{Some Considerations on the Most Dense Packing of the Grog Grains in the Manufacture of Fire Clay Bricks}

Relations on the Property in System, Compressive Specific Value-Porosity-Raw Materials

By Susumu NAGASAKI and Morio AMAFUJI

(Kyūsyū Fire Brick Co., Ltd.)

\begin{abstract}
The authors could sufficiently study the theory about the dense packing of the grog grains from the detailed reports, which were made by H.E. White \& S.F. Walton or by A.E.R. Westman \& H.R. Hugill.

They applied the obove theory on the practical operations and obtained some interesting results.

For instance the following facts were found by them that the proper value of Specific volume of raw materials affected the property of packing grains, and moreover the limit of lowest porosity was defined against the products of fire clay bricks.
\end{abstract}

\section{緒言}

粘土一水一空気系 (clay-water-air system) の成形 機構については，圧縮比容曲線によって理解すること が出来古(第1図).この考光方子耐火煉瓦の成形汇関 して考察した例を昭和 29 年 4 月嘿業協会大阪支部主 催学術講演会で発表した，その際耐火龽瓦素地坏土の
比容の性質全般について，另らかじめ系統的飞究めて 和くことの必要を力説した.

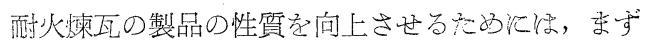
素地坏土の最密充填を論議しなければなららなが，圧 縮比容曲線はこの目的を果すためねばななだ有効な役 割を果するのであると思う。この論文で活主として死 